\title{
Response Of The Dupi Tila Aquifer To Intensive Pumping In Dhaka, Bangladesh.
}

\author{
Brian L Morris, Ashraf Ali Seddique, KaZi matin Ahmed \\ Brian L Morris (凶): British Geological Survey, Maclean Building, Crowmarsh Gifford, \\ Wallingford, Oxon OX10 8BB, UK. \\ e-mail: blm@bgs.ac.uk Fax 441491 692345, Tel 441491838800
}

Ashraf A Seddique, K matin AhMed

Ashraf Ali Seddique, Kazi Matin Ahmed: University of Dhaka, Dept of Geology, Dhaka 1000, Bangladesh.

e-mail: kmahmed@udhaka.net Fax 88028615583 Tel 8802 9661900-59, Ext 4897, 6015.

\begin{abstract}
This paper focuses on the water-quantity issues facing Dhaka because of the rapid exploitation of the Dupi Tila aquifer. Dhaka is one of the world's largest groundwater-dependent cities, relying on water withdrawn from this underlying semiconfined sand aquifer. A meteoric rise in well construction in both the private and public sectors in recent years has produced an estimated 1,300 boreholes that tap the aquifer in urban and suburban parts of the city. Analysis of construction records for public-supply wells drilled between 1970 and 2000 shows that water levels are falling in several areas of the city despite apparently favorable recharge conditions. The productivity of boreholes as measured by specific capacity has also declined significantly. Even though the aquifer system is vital to the infrastructure of the city it remains a poorly quantified resource, and until this is resolved by investment in evaluation studies, attempts to efficiently manage the resource in a sustainable way will be frustrated.
\end{abstract}

Keywords Bangladesh Urbangroundwater Waterlevels Borehole design

\section{Introduction}

The inexorable global rise in the proportion of people that live in cities continues apace, such that by 2010 it has been estimated that half the then global population of seven billion will be urban dwellers, compared to less than 30\% in 1950 (UNCHS, 1987). Much of this increase has been concentrated in the developing world. Nowhere is this better illustrated than in Bangladesh where the proportion of population that is urban grew from less than one in seven in 1980 to almost one in four in 1999 (World Bank, 2000). The capital, Dhaka, had a 1985 population of 4.9 million (UNEP, 1992) which grew to 7.8 million by 1995 (UNPD, 1995) and with a more than 5\% annual growth rate is expected to have achieved megacity status of 10 million+ by 2000 . It is now one of the world's 25 largest cities. 


\section{Groundwater Setting of Dhaka}

Dhaka is more than $95 \%$ dependent on groundwater for domestic, industrial, and commercial water supply. The rise in groundwater use over the last 50 years continues apace, from the drilling of the first borehole in 1949 to more than 190 public-supply and 200 private boreholes together abstracting an estimated $310 \mathrm{Mm}^{3}$ per year in 1998 (Ahmed et al. 1999). New investment in the late 1990s has significantly increased the number of public-supply boreholes operated by the utility, Dhaka Water Supply and Sewerage Authority (DWASA). As a result, groundwater withdrawals have accelerated such that by late 2000 DWASA was operating more than 330 wells and pumping approximately $400 \mathrm{Mm}^{3}$ per year of water into the supply. Abstraction from private boreholes, whose numbers have also expanded dramatically to more than 970 (DWASA, 2000), is unquantified but likely to be substantial.

All water is obtained locally from underlying fluvio-deltaic sands of the highly productive Dupi Tila aquifer, which is locally reported to be about $140 \mathrm{~m}$ thick. These Plio-Pleistocene sediments, with a transmissivity typically in the range $500-2,000 \mathrm{~m}^{2} / \mathrm{d}$ are considered to be of limited extent in the environs of Dhaka. They occupy a horst that extends southwards from the main outcrop/subcrop north of the city, as shown in Figure 1. More recent Quaternary fluvio-deltaic sediments on either side of this southerly fault-bounded block are composed predominantly of silts and clays of the Madhupur Formation and younger alluvium. These are much less permeable, typically about $0.01 \mathrm{~m} / \mathrm{d}$ for the clays and $0.1 \mathrm{~m} / \mathrm{d}$ for the silts. Such a groundwater setting implies that the Dupi Tila aquifer, confined beneath the leaky Madhupur Formation, comprises a groundwater resource that is large, but by no means infinite.

\section{Figure 1}

The very low elevations, the proximity of the Rivers Buriganga, Turag and Balu to the southwest, west and east, and the risk of flooding have historically constrained the direction of expansion of Dhaka. This has meant that until recently new industrial/commercial and residential development 
has tended towards the north, in effect coincident with the extent of the Dupi Tila aquifer. It has therefore continued to be possible to provide water from intra-urban wells, without the need for complex water-transfer systems from peri-urban wellfields or distant surface-water sources. The corollary is that recharge to the Dupi Tila sands, either directly via near-city reaches of the Buriganga River or indirectly by leakage through the confining Madhupur clay, is increasingly influenced by urban processes.

Such processes can often have the effect of increasing the overall availability of recharge (Foster et al, 1993) but at a cost in terms of chemical and biological water quality (Morris et al 1994, Lawrence et al. 1997, Ellis 1997). In the case of Dhaka, some water-quality deterioration has already taken place as urban recharge (direct or indirect) impacts on the baseline water quality of the Dupi Tila sands. By 1996 significant increases in electrical conductivity from a background of less than $200 \mu \mathrm{S} / \mathrm{cm}$ to more than $600 \mu \mathrm{S} / \mathrm{cm}$ were being observed in the older industrial district located near the Buriganga River (Ahmed et al. 1999). The influx of urban recharge directly or indirectly is also evidenced by depleted oxygen and hydrogen stable isotope ratios in samples from boreholes in the south of the city near the River Buriganga and in the area of maximum piezometric decline (Darling et al, pers. comm. 2001). The rapid increase in groundwater withdrawals in the late 1990 s is likely to accentuate this trend.

However, issues other than declining water quality may in the future affect Dhaka's water supply. This paper uses public-supply borehole drilling records from 1970 to 2001 to assess the effect of increasing abstraction on well productivity. For a given groundwater demand, average well productivity will control not only the number and spacing of boreholes in an urban wellfield, but also the energy costs incurred in pumping the water into the supply. If the productivity of an aquifer is declining, both capital and operating costs are thus increased, and this can impact particularly on public water supply, where economic cost recovery can be a difficult issue. It is even more sensitive in Bangladesh than elsewhere because of the level of urban and rural poverty. With a per capita GNP of US\$ 370 (1999), it has been estimated that in $199678 \%$ of the population subsisted on less than US\$ 2 per day per person (World Bank, 2000). Even apparently trivial increases in unit water cost will have a disproportionately greater impact when passed on to consumers living at or below this poverty line. This is a delicate issue for one of the poorest megacities in one of the world's poorest countries. 


\section{Trends in Water Levels, Productivity and Borehole Design}

\section{Water levels}

Dhaka is zoned for water-supply purposes into six districts, with newer zones having the higher numbers. Zones 1 and 2 are in the older more densely populated southern part of the city and Zone 6 coincides with the major industrial district of Tejgaon located north of the old city centre (Figure 2). Zones 1, 2 and 6 have seen the most intensive well development, but during the 1990s new drilling has increasingly extended to the other supply zones.

\section{Figure 2}

Based on sparsely available monitoring-well information Ahmed et al. (1999), have already reported declines in piezometric water levels in Dhaka. By 1995, widespread pumping had induced the formation of an extensive cone of depression centred on the southern part of the city with up to a 25-metre depression of the regional water level.

By the late 1990s, pumping in these areas from an ever-increasing density of public-supply and private wells had resulted in piezometric levels of more than $35 \mathrm{~m}$ below ground level. Away from these zones, in which there is a high density of water-supply boreholes, new wells could still encounter static water levels which, although depressed in comparison with the pre-urban state, were still only about $10 \mathrm{~m}$ or so below the pre-development condition. These two trends, which started in the 1970s, are well illustrated in Figure 3 which shows static water levels at the date of construction of 329 boreholes drilled for DWASA between 1970-2000.

\section{Figure 3}

Figure 4, which records pumping water levels in new wells at the date of commissioning, shows that individual pumping lifts were by the late 1990 s exceeding $55 \mathrm{~m}$ in the most heavily exploited areas. This compares with less than $15 \mathrm{~m}$ in the early 1970s. Averaged over the three most intensively exploited zones 1, 2 and 6, pumping lifts increased from 19m in the early 1970s, through $28 \mathrm{~m}$ in the $1980 \mathrm{~s}, 42 \mathrm{~m}$ in the late $1990 \mathrm{~s}$, to $48 \mathrm{~m}$ by 2001.

\section{Figure 4}




\section{Productivity}

In order to simplify and standardise test-pumping plant and subsequent pumping station design, water-supply boreholes in Dhaka have for many years been designed and step-tested for a production rate of 2 cubic feet/sec $(56.6 \mathrm{1} / \mathrm{s})$. A standardised pumping rate permits a direct comparison of specific capacities and temporal trends from the borehole construction records of 342 public-supply wells constructed between 1970 and 2001. Figure 5 shows that since the early 1970s there has been a steady decline in specific capacity, from $6.3 \mathrm{l} / \mathrm{s} / \mathrm{m}$ in the $1970 \mathrm{~s}$ to $4.5 \mathrm{l} / \mathrm{s} / \mathrm{m}$ in 1991 2000. This represents a decline of almost $30 \%$ in the productivity of a typical public-supply well.

\section{Figure 5}

\section{Borehole Design}

The DWASA public-supply borehole construction records provided individual site information on borehole number, depth, date drilled, length of upper plain casing housing the pump, lower plain casing and screen, design discharge, and static and pumping water level at the commissioning date. Wells have a standard design of large-diameter pump casing extending from the surface into which is telescoped plain casing above a screened interval above a sand sump. For trend-analysis purposes, the wells were divided into those drilled during the 1970s, the 1980s and the 1990s, and into zone subsets. Average values for the length of well linings are summarised in Table 1. Some observations include:

\section{Table 1}

- The average installed length of pump casing has progressively increased from $41 \mathrm{~m}$ in the $1970 \mathrm{~s}$ to $71 \mathrm{~m}$ in the late $1990 \mathrm{~s}$. This reflects recognition of the need to design for initial pump settings at progressively lower depths as regional water levels decline, and to consider the need for a future resetting of production pumps as regional levels continue to fall

- Much of this increase has been accommodated for by a reduction in the smaller diameter plain casing length above the screen.

- Screen lengths have consequently seen only a modest increase both in length (of about $8 \mathrm{~m}$ to an average of $95 \mathrm{~m}$ in the 1990s) and in their midpoint depth settings (from 110m to approximately $120 \mathrm{~m})$. 
- As a result, average well depth has increased by only about $12 \mathrm{~m}$ since the $1970 \mathrm{~s}, 2 \mathrm{~m}$ of which is accounted for by a trend towards deeper sand sumps to accommodate fine sediment entrained during pumping.

The average values for the lengths of various well-linings for the whole city mask some variation in trend within the supply sectors, especially in heavily exploited Zones 1 and 2, where well design has had to accommodate the lowest water levels as interference effects and dewatering become more marked. Table 2 shows how this has affected the depth at which screens are set. In Zone 1 the midpoint screen depth increased by $18.5 \mathrm{~m}$ (equivalent to about $0.75 \mathrm{~m} /$ year over the review period), whereas in the more lightly developed Zones 4 and 5 the screen depth remained relatively unchanged.

\section{Table 2}

\section{Hydrogeological Significance of Falling Water Levels in the Dhaka Aquifer}

The Dupi Tila aquifer beneath Dhaka benefits from a relatively favourable recharge regime. Annual average rainfall exceeds $2,500 \mathrm{~mm}$. Moreover the city is located adjacent to distributaries of the gigantic Ganges-Brahmaputra-Megna river system which, as has already been established (Ahmed et al. 1999, Darling et al. 2001), ensures induced recharge is possible through the Buriganga river bed Additional major new sources of recharge are now available from the urban infrastructure via pipe leakage (water mains, sewers, storm drains), on-site sanitation, and pluvial drainage. So there appears to be ready water availability. It is therefore of concern not only that water levels are falling across such an extensive part of the city, leading to increased pumping costs, but also that well productivity should be declining too.

Following are several possible reasons for the trends described earlier, of which the first two are likely to be the more important:

(i) The principal explanation for the trend of falling levels despite apparently ample sources of recharge at the surface is likely to be a result of the particular hydrogeological setting of the city. The Dupi Tila aquifer is confined by the leaky Madhupur Formation of silty clays, which is patchy but on average about $10 \mathrm{~m}$ thick beneath Dhaka. As seasonal water levels have fallen from a few metres below ground level in the $1970 \mathrm{~s}$ to $25 \mathrm{~m}+$ in the late $1990 \mathrm{~s}$, 
the aquitard has been drained and the upper part of the Dupi Tila is now being dewatered. Once saturated conditions give way to unsaturated, the vertical hydraulic conductivity is reduced, especially in the uppermost finer-grained strata where narrow pore necks become filled with air and obstruct water passage. Although the Dupi Tila is in places sufficiently dewatered to have become unconfined, changes from the initial leaky confined response of wells to pumping also reflect the reduced amount of recharge to the aquifer as the hydraulic resistance increases. In effect, the drawdown-limiting tendency for free drainage from the aquifer under unconfined conditions is counterbalanced by a reduced capacity for leakage through the aquitard. In the case of the Dhaka aquifer, drawdowns have increased, and therefore specific capacities have decreased. Figures 5 and 6 illustrate these effects.

\section{Figure 6}

(ii) A second explanation lies in progressive reduction of transmissivity or effective thickness as pump casings are deepened but well depths stay the same. As a hydraulic approximation, unless the well has a large diameter-to-length ratio, the depth to the bottom of the lowermost screen effectively defines the base of the aquifer in the near-well zone around a borehole. It is therefore quite likely that many wells in Dhaka are experiencing dewatering effects as the saturated thickness originally tapped by those wells declines. This effect will be especially marked within the cone of drawdown and will compound the more widespread water-level depression experienced across heavily-pumped zones of the city. The actual thickness of the Dupi Tila aquifer has not been reliably mapped for the Dhaka area and there is some indication from recent (post-1998) drilling that productive zones of the aquifer may extend significantly below the $150 \mathrm{~m}$ below ground level which is typically cited as the base of the Dupi Tila aquifer beneath the city. This means that the reduction in effective thickness which is affecting some older central-zone boreholes is independent of actual aquifer thickness, being instead a function of well depth and design.

(iii) Deterioration due to encrustation, plugging, dewatering, or other gradual performancelimiting processes. This may be excluded as a cause because the specific-capacity data are derived from newly commissioned wells.

(iv) A steady change with time towards less efficient well designs/completions. While the downward trend in static water levels illustrated in Figure 3 shows that falling water levels are aquifer-wide in some of the city's distribution zones, it is possible that the effect may be compounded by declining well-screen efficiency. Reductions in well efficiency could be 
due to deterioration either in drilling/well development practices or in screen specifications. There is no information on this aspect, which would in practice be difficult to disentangle from well interference effects in such a densely exploited urban aquifer. However, if it is a contributory effect, its magnitude appears to be small, as the average drawdown in DWASA boreholes (which would include the effects of interference in several distribution zones) has only increased from $11.0 \mathrm{~m}$ in the $1970 \mathrm{~s}$ to $13.1 \mathrm{~m}$ in the $1990 \mathrm{~s}$.

(v) A change with time as well screens are set lower to deeper aquifer horizons. Variations in permeability with depth in the Dupi Tila sands have unfortunately not been recorded and are unknown. Tables 1 and 2 show that with one exception, well designers have not significantly deepened screen settings over the 30-year period under review. The exception is Zone 1 where a systematic increase, from $120 \mathrm{~m}$ to $139 \mathrm{~m}$, is noted. This trend however affects less than $18 \%$ of all wells considered in the dataset, and screen lengths and settings elsewhere have remained broadly unchanged. Thus it is not possible to ascertain whether deeper horizons of the Dupi Tila are more permeable because in general they have not yet been tapped. Equally, however, changes in screen setting with time can be discounted as contributory to productivity declines.

(vi) Permeability reduction in the Dupi Tila sands northwards away from the axis of the River Buriganga, causing a reduction in the mean values as new wells are increasingly drilled in northwestern and northeastern sectors of metropolitan Dhaka. This may be a possibility but there are no field permeability or transmissivity data available to either support or refute the hypothesis. It is observed that no significant geographical pattern of median or interquartile range emerged from a statistical analysis of specific capacity by city zone (Figure 7). However it is recognised that specific capacity results are not necessarily a reliable indicator of possible changes in permeability/storage release because they may also depend on other factors in a heavily exploited aquifer (such as degree of development leading to interference effects).

\section{Figure 7}

\section{Discussion}

The nine-parameter data set used in this paper (borehole number, depth, date drilled, length of upper plain casing housing the pump, lower plain casing and screen, design discharge, and static and pumping water level at the commissioning date) represents 30 years of public water supply borehole construction for Dhaka. It shows that despite the city's location in a zone of ample annual effective 
precipitation and its proximity to a major hydraulically-connected river system, the aquifer providing $95 \%$ of the city's water-supply needs is experiencing major declines in water levels. Falling water levels have adversely affected the productivity of new city public-supply wells, which during the boom in well drilling of the 1990s have shown a specific capacity almost 30\% lower than their equivalents from the 1970 s.

Recharge mechanisms to an urban/urbanising aquifer are complex but one global conclusion emerging from the relatively few studies carried out to date on groundwater-dependent cities is that irrespective of climatic regime, the quantity of recharge tends to increase, reflecting the rise in potential sources of water that can infiltrate from the city water and drainage infrastructure. Figure 8 for instance summarises the results from twelve cities in different climatic regimes. It is not known if increased post-urbanisation recharge is the case for the Dhaka aquifer, where so far there have been no significant water imports via mains into the city from the periurban/rural hinterland. Even if recharge is increasing it does not appear to be keeping pace with rising abstraction, so water levels are falling as withdrawals from storage occur instead.

\section{Figure 8}

The specific capacities of the 329 DWASA boreholes which are analysed here refer only to the productivity of the wells at the date of commissioning. A modern re-survey of the boreholes is needed in order to compare changes in site values over time. It is logical to expect that the productivity of the older wells located in zones now heavily exploited would be substantially less than at the date of commissioning, and this would further demonstrate the hidden cost of unmanaged withdrawals from the urban aquifer. Similarly, it would be instructive to conduct an economic analysis demonstrating the present additional cost of the energy required to cope with the increased lift and likely future additional costs arising from changes in well and pumping-plant design, which are required as regional water levels decline (deepening of wells; and installation of longer large-diameter pump casings and longer screen sections).

There is no information available on the performance of private boreholes, but it seems likely that the trend in the same areas of the city will be similar. The construction of new boreholes continues apace, both by the water utility DWASA and by the private sector. 
Despite the most extensive exploitation and its vital role in Dhaka's water infrastructure, the Dupi Tila aquifer system remains relatively poorly studied and poorly understood. The summaries of DWASA borehole construction used in this paper for instance indicate that even the geometry of the aquifer remains uncertain. Aquifer characteristics have been only sporadically determined at a few sites and recharge mechanisms and magnitude remain unquantified. This continuing paucity of investment in basic resource evaluation limits the confidence with which urban water-supply managers can recalibrate and apply predictive tools such the aquifer model established for the city area in the early 1990s. Lack of such aquifer data seriously hampers proactive urban water management, for which reliable predictive modeling of different operating and regulatory scenarios is a prerequisite (Foster et al 1998).

\section{Conclusions}

The existence of the thick and productive Dupi Tila aquifer beneath Dhaka has been of immeasurable benefit to a city with poor financial resources that has doubled in size to megacity status in only 15 years or so. Groundwater drawn locally from this aquifer continues to be the prime source to meet demands for domestic, industrial, and commercial water supplies provided either by the public utility or by private well owners. However the aquifer has limitations in areal extent and the local geography has conspired to focus much of Dhaka's expansion northwards across more and more of the aquifer's outcrop/subcrop.

This urbanisation trend will be matched by increasing abstraction and major changes in recharge patterns, yet unfortunately it is taking place in an aquifer system that remains very poorly understood as a result of inadequate investment in scientific groundwater investigation and quantification. As a resource supplying one of the world's poorest large cities in one of the world's poorest countries, the aquifer requires sustainable management not only to protect future water quality but also to ensure that the resource can continue to meet the quantitative demands being placed upon it.

Acknowledgements This paper is published by permission of the Director, British Geological Survey (NERC). The study has been made possible by the support of the UK Department for International Development. The authors thank colleagues for helpful discussion and especially Dhaka Water Supply and Sewerage Authority (DWASA) for providing the borehole construction information that forms the principal data source for this paper. 


\section{REFERENCES}

Ahmed K H, Hasan M K, Burgess W G, Dottridge J, Ravenscroft P and van Wonderen J J (1999) The Dupi Tila aquifer of Dhaka, Bangladesh: hydraulic and hydrochemical response to intensive exploitation. In Groundwater in the Urban Environment: Selected City Profiles, P J Chilton (ed.) Balkema, Rotterdam,19-30

Darling W G, Burgess W G and Hasan M K (pers.comm. 2001) Isotopic evidence for induced river recharge to the Dupi Tila aquifer in the Dhaka urban area, Bangladesh

DWASA (2000) Management Information Report for the Month of November 2000. Dhaka Water Supply and Sewerage Authority, Dhaka Bangladesh

Eiswirth M, Wolf L and Hotzl H 2002. Balancing the contaminant input into urban water resources. In: Procs XXXII IAH and VI ALHSUD Congress on groundwater and human development. Mar del Plata 21-25 October 2002

Ellis J B (1997) Groundwater pollution from infiltration of urban stormwater runoff. In Groundwater in the Urban Environment: Problems Processes and Management, P J Chilton et al (eds.) Balkema, Rotterdam, 131-136

Foster S S D, Morris B L and Lawrence A R (1993) Effects of urbanisation on groundwater recharge. ICE International Conference on Groundwater Problems in Urban Areas, London, June 1993.

Foster S S D, Lawrence A R, Morris B L (1998) Groundwater in urban development: assessing management needs and formulating policy strategies. World Bank Technical Paper 390, WB Washington DC.

Krothe J N, Garcia-Fresca B and Sharp Jr. J M 2002. Effects of urbanisation on groundwater systems. In: Procs XXXII IAH and VI ALHSUD Congress on groundwater and human development. Mar del Plata 21-25 October 2002

Lawrence A R, Morris B L, Gooddy D C, Calow R and Bird M J (1997) The study of the pollution risk to deep groundwaters from urban wastewaters: project summary report. British Geological Survey Technical Report WC/97/15, Keyworth UK.

Morris B L, Lawrence A R and Stuart M E (1994) The impact of Urbanisation on Groundwater Quality (Project Summary Report). British Geological Survey Report WC/94/56.

UNCHS (1987) Global Report on Human Settlements. UN Centre for Human Settlements, Oxford University Press, New York UNEP (1992) The World Environment 1972-92, UNEP Nairobi

UN Population Division (1995) World urbanisation prospects, 1994 revision. UN New York 1995, Tables A12, A14

World Bank (2000) World Development Report 2000-2001. Oxford University Press New York

Figure 1 Groundwater setting of Dhaka (modifed from Ahmed et al. 1999)

Figure 2 Public water supply distribution zones of urban area of Dhaka

Figure 3 Decline in construction-date static water levels in Dhaka public-supply wells, 1970-2000

Figure 4 Decline in construction-date pumping water levels in Dhaka public-supply wells, 1970-2000

Figure 5 Productivity decline in newly-commissioned Dhaka public-supply wells, 1970-2000

Figure 6 Response of Dhaka aquifer to effects of intensive abstraction.

Figure 7 Percentile distribution diagram for specific capacity by water-supply distribution zone

Figure 8 Increase in groundwater recharge due to urbanisation (modified from Foster et al 1993, Krothe et al. 2002, Eiswirth et al. 2002) 


\begin{tabular}{llll}
\hline \multicolumn{1}{c}{ Length (m) } & $\mathbf{1 9 7 0 - 8 0}$ & $\mathbf{1 9 8 1 - 9 0}$ & $\mathbf{1 9 9 1 - 0 0}$ \\
\hline Pump housing & 41 & 49 & 71 \\
Plain casing & 46 & 45 & 24 \\
Sub-total plain & $\mathbf{8 7}$ & $\mathbf{9 4}$ & $\mathbf{9 5}$ \\
Screen section & 48 & 50 & 50 \\
$\begin{array}{l}\text { Midpoint screen } \\
\text { depth }\end{array}$ & 110 & 119 & 120 \\
Sand sump & 2 & 3 & 4 \\
Total depth & $\mathbf{1 3 7}$ & $\mathbf{1 4 7}$ & $\mathbf{1 4 9}$ \\
\hline
\end{tabular}

Table 2 Average midpoint screen depths in metres below ground level, DWASA boreholes 1970-2000

\begin{tabular}{llll}
\hline City Zone & $\mathbf{1 9 7 0 - 8 0}$ & $\mathbf{1 9 8 1 - 9 0}$ & $\mathbf{1 9 9 1 - 0 0}$ \\
\hline Zone 1 & 120.3 & 126.1 & 138.8 \\
Zone 2 & 105.5 & 118.9 & 115.5 \\
Zone 3 & - & 97.6 & 106.6 \\
Zone 4 & - & 104.9 & 100.3 \\
Zone 5 & - & 125.8 & 123.4 \\
Zone 6 & - & 125.3 & 130.6 \\
All zones & 110.4 & 118.8 & 119.9 \\
\hline
\end{tabular}




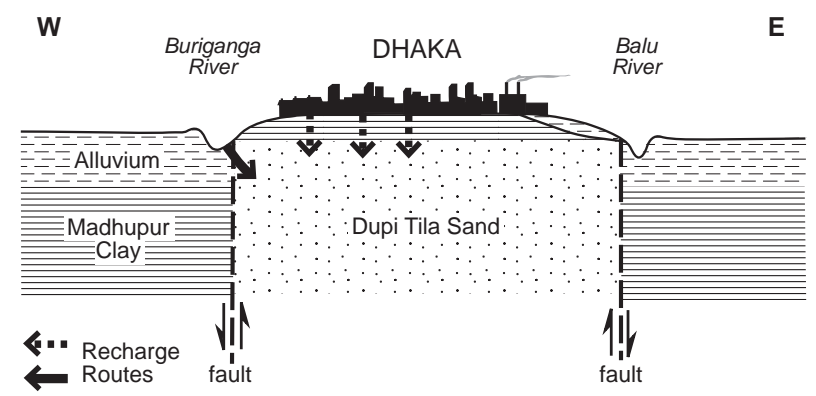

Figure 1 Groundwater setting of Dhaka (modifed from Ahmed et al.1999)

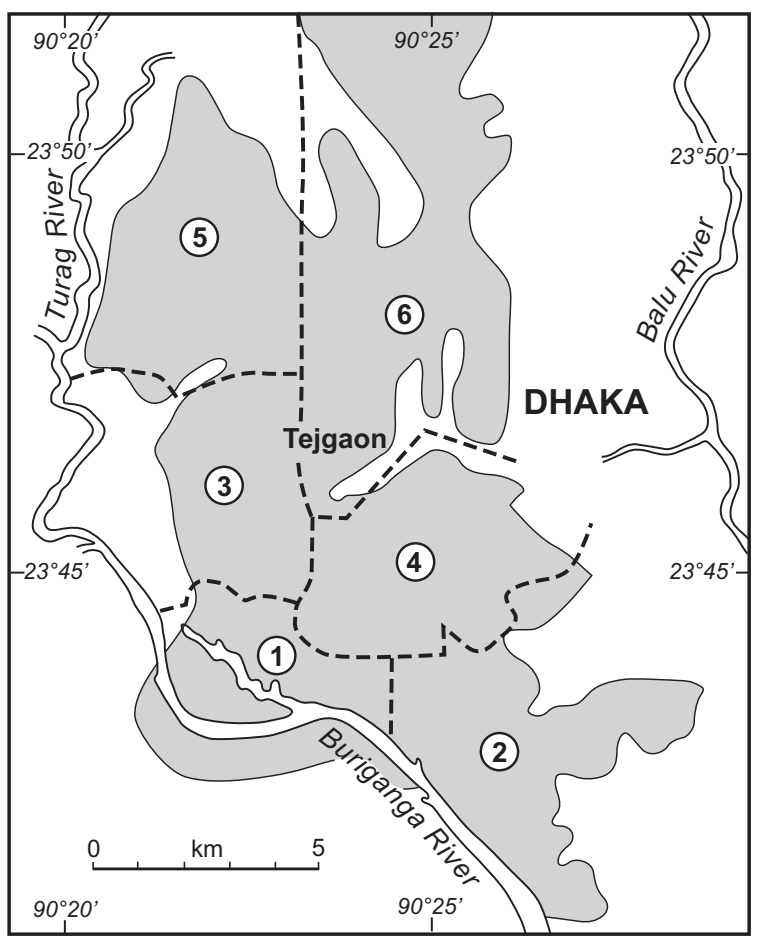

Figure 2 Public water supply distribution zones of urban area of Dhaka 


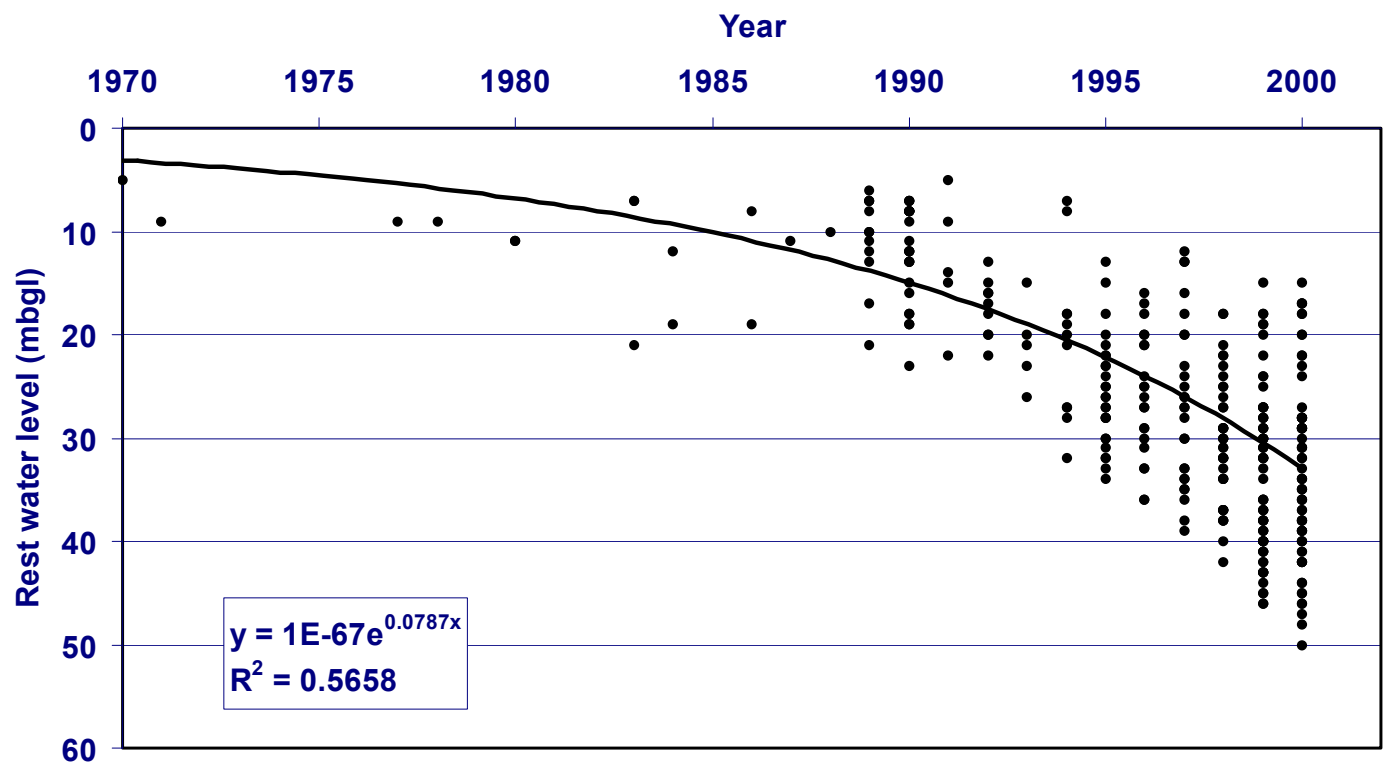

Figure 3 Decline in construction-date static water levels in Dhaka public-supply wells, 1970-2000

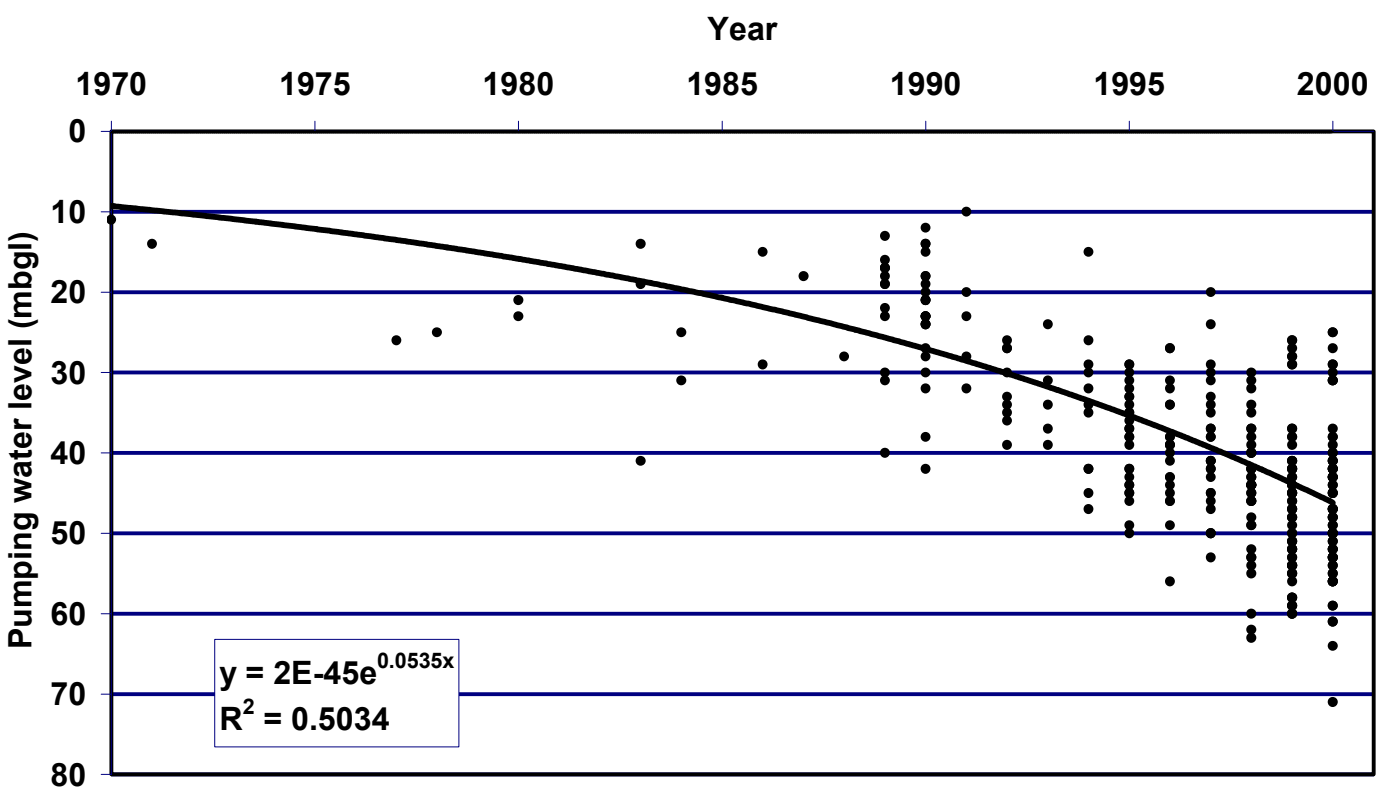

Figure 4 Decline in construction-date pumping water levels in Dhaka public-supply wells, 19702000 


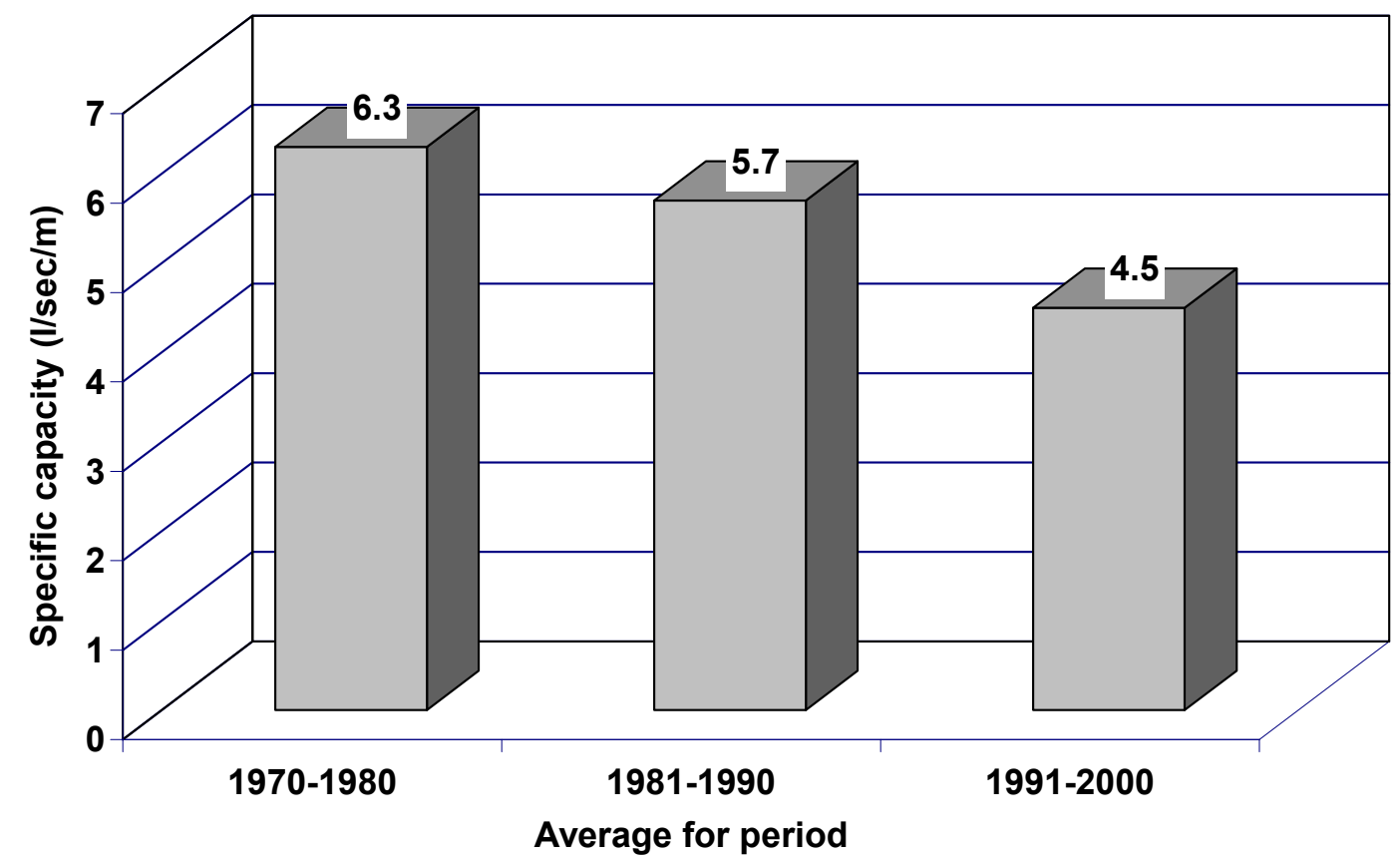

Figure 5 Productivity decline in newly-commissioned Dhaka public-supply wells, 1970-2000

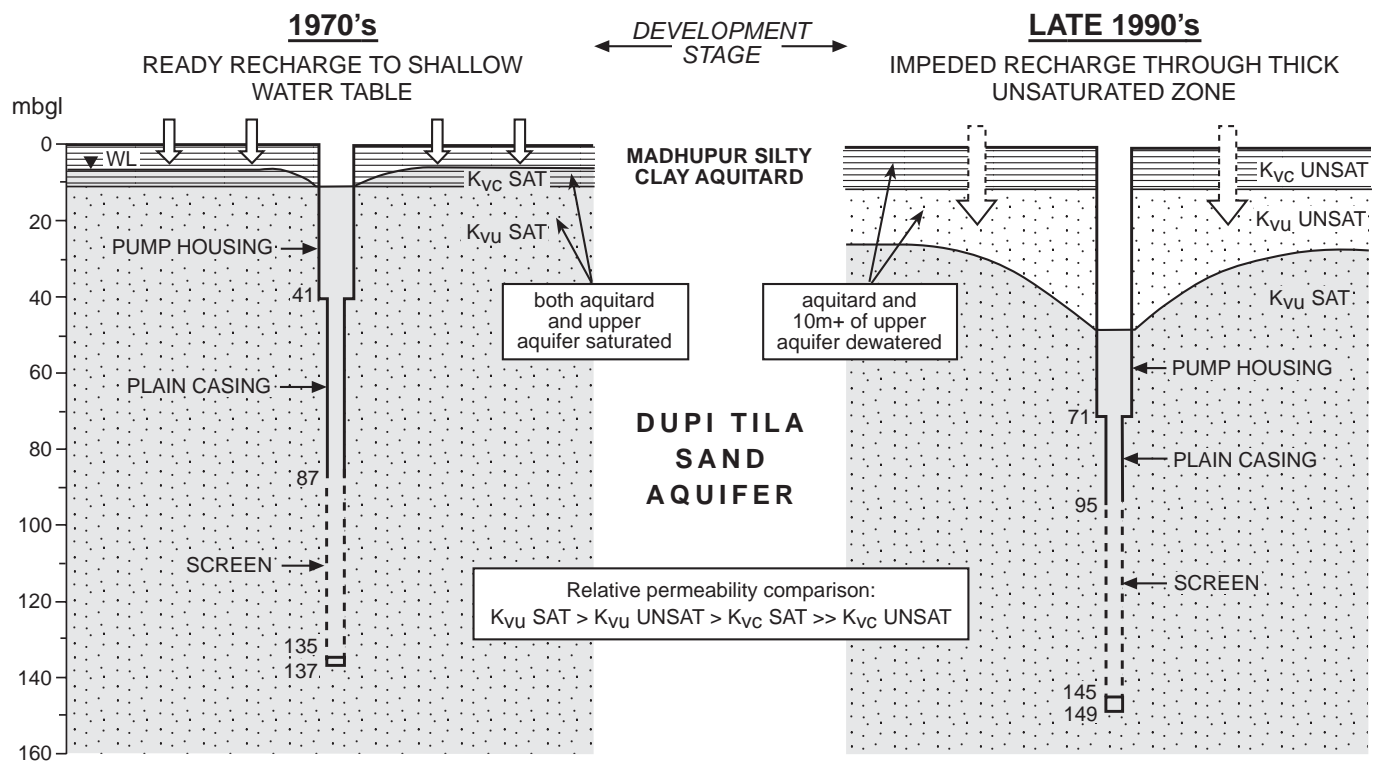

Figure 6 Response of Dhaka aquifer to effects of intensive abstraction. 

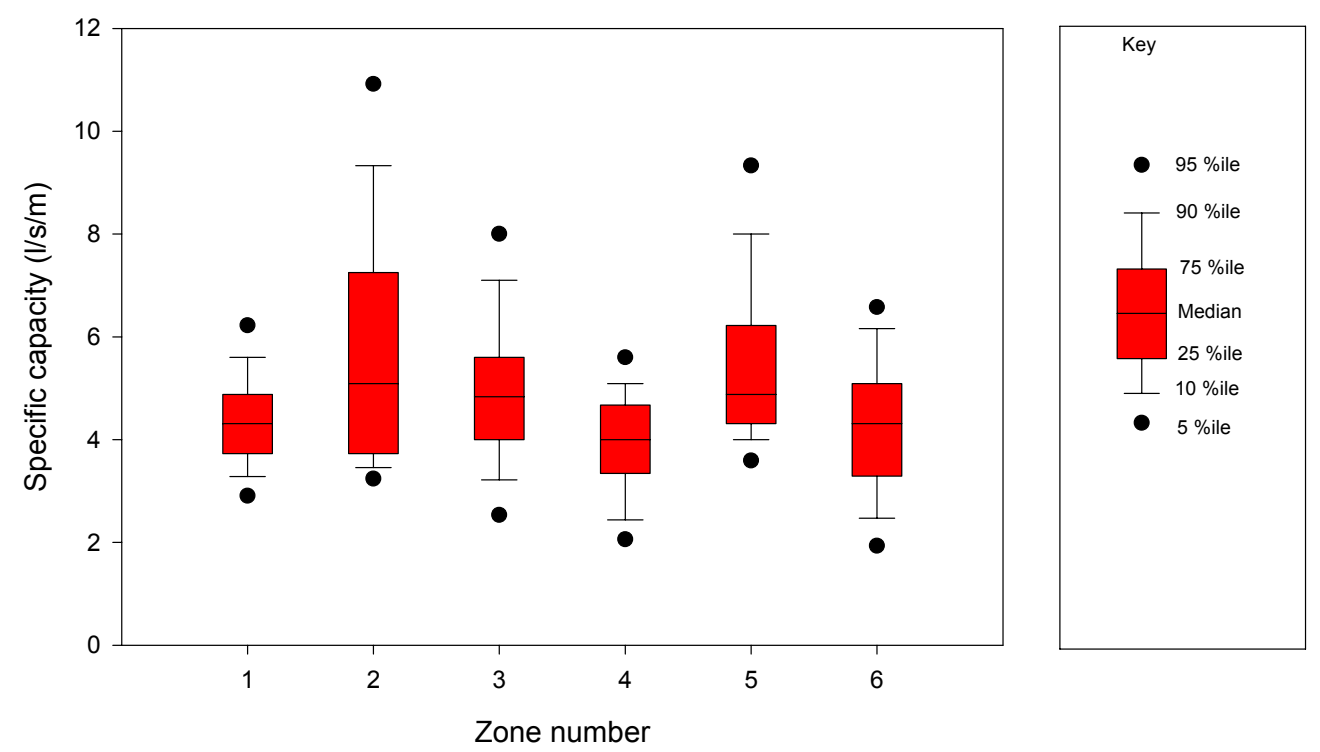

Figure 7 Percentile distribution diagram for specific capacity by water supply distribution zone

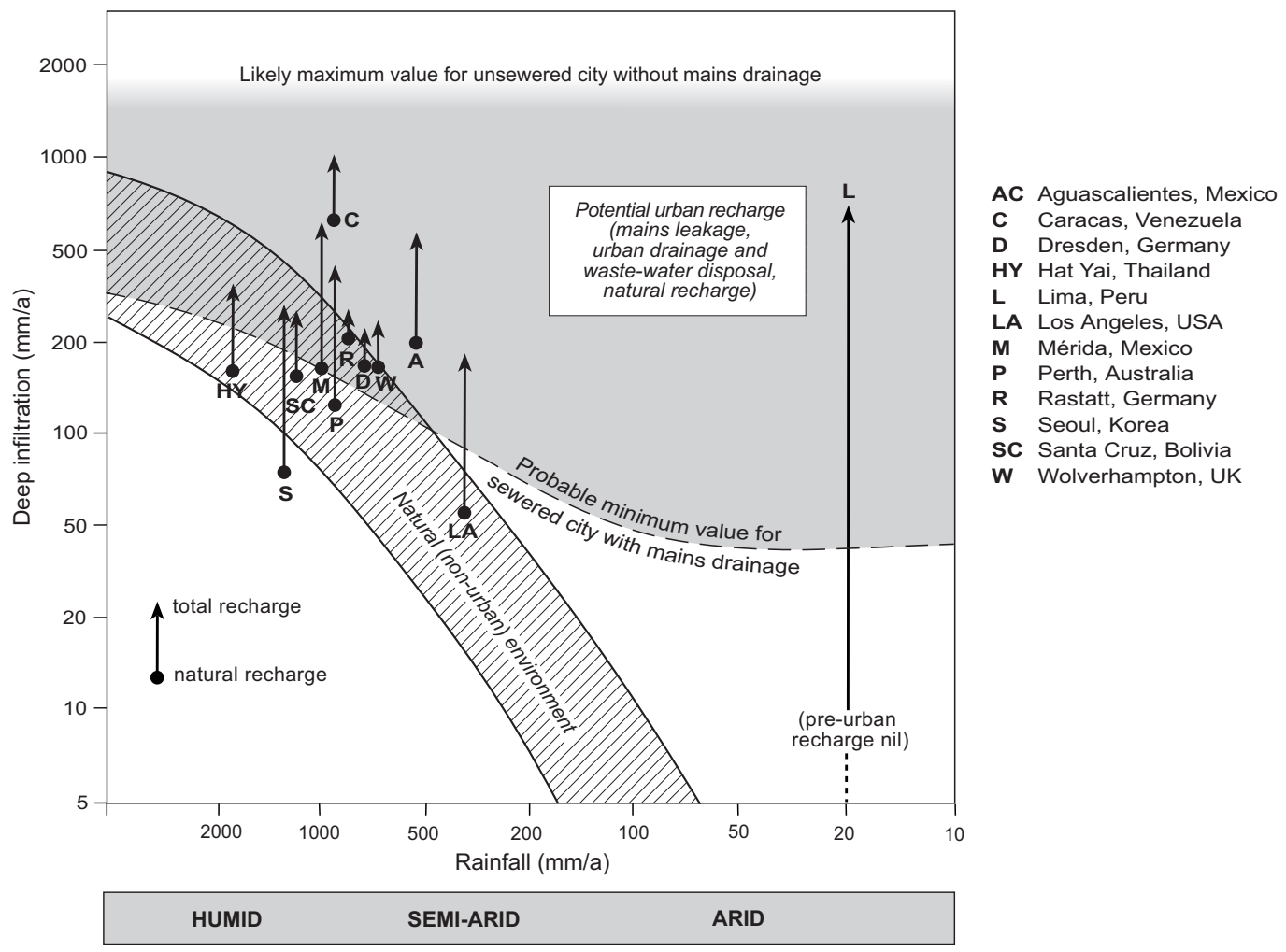

Figure 8 Increase in groundwater recharge due to urbanisation (modified from Foster et al. 1993, Krothe et al. 2002, Eiswirth et al. 2002) 